\title{
Peningkatan Prestasi Belajar Mapel IPA Melalui Metode Eksperimen
}

\author{
Sariyem $^{(1)}$ \\ ${ }^{1}$ Guru SDN 2 Ngulankulon Kecamatan Pogalan Trenggalek \\ Email: ${ }^{1}$ sariyem1983@gmail.com, \\ DOI: https://doi.org/10.28926/riset_konseptual.v2i3.65
}

\begin{abstract}
ABSTRAK
IImu Pengetahuan Alam (IPA) itu sendiri merupakan ilmu yang mempelajari gejala alam melalui proses dan sikap ilmiah yang pada dasarnya masih dilakukan dengan pembelajaran yang berpusat pada guru dengan metode cerama. Sedang pada intinya proses ilmiah didasari dengan cara berfikir logis berdasarkan fakta-fakta yang mendukung sikap ilmiah tercantum pada sikap jujur dan obyektif dalam mengumpulkan fakta dan menyajikan hasil analisis fenomena- fenomena alam. Tujuan yang hendak dicapai dari penelitian ini adalah sebagai berikut: Mengetahui implementasi metode eksperimen terhadap peningkatan Prestasi Belajar siswa pada pembelajaran IPA tentang gaya Kelas IV SDN 2 Ngulankulon Kecamatan Pogalan Kabupaten Trenggalek Semester 2 tahun pelajaran 2016/2017. Subjek penelitian ini adalah siswa Kelas IV SDN 2 Ngulankulon Kecamatan Pogalan Kabupaten Trenggalek Semester 2 Tahun Pelajaran 2016/2017 yang berjumlah 24 siswa, yang terdiri dari 13 siswa laki-laki dan 11 siswa perempuan. Hasil penelitian menunjukkan peningkatan hasil belajar siswa, pada akhir siklus I siswa tuntas mencapai 25 siswa (78\%), sedangkan pada akhir siklus II mencapai 29 siswa $(91 \%)$. Kenaikan atau peningkatan ketuntasan belajar adalah sebanyak 4 siswa atau $13 \%$. Kesimpulan yang dapat diperoleh bahwa penggunaan metode eksperimen dalam pembelajaran, terbukti dapat meningkatkan hasil belajar siswa pada siswa Kelas VI Semester II Tahun Pelajaran 2016/2017 di SDN 3 Ngadirejo Kecamatan Pogalan Kabupaten Trenggalek.
\end{abstract}

Kata kunci: ipa, prestasi belajar, eksperimen

\section{PENDAHULUAN}

Pendidikan merupakan media yang sangat berperan untuk menciptakan manusia yang berkualitas dan berpotensi dalam arti yang seluas-luasnya, melalui pendidikan akan terjadi proses pendewasaan diri sehingga di dalam proses pengambilan keputusan terhadap suatu masalah yang dihadapi selalu disertai dengan rasa tanggung jawab yang besar. Kegiatan pembelajaran IPA lebih diarahkan kepada kegiatan- kegiatan yang mendorong siswa belajar aktif secara fisik, sosial, maupun psikis dalam memahami konsep, yaitu dengan menggunakan berbagai keterampilan proses. Melalui cara berfikir logis dan sikap jujur serta obyektif tersebut dihasilkan suatu hasil atau produk berupa penjelasan atau deskripsi tentang fenomena-fenomena alam beserta hubungan kausalitasnya. Kegiatan pembelajaran IPA meliputi penyentuhan, perakitan, pemanipulasi, percobaan dan penginderaan.

Prabowo (2000:43), pendidikan dapat mutu ditingkatkan melalui berbagai upaya, antara lain: pengembangan kurikulum, peningkatan mutu tenaga kerja, pengembangan kualitas proses pembelajaran, dan terciptanya lingkungan belajar yang kondusif.

Metode eksperimen adalah cara penyajian pelajaran dengan memperagakan atau mempertunjukkan kepada peserta didik suatu proses, situasi atau benda tertentu yang sedang dipelajari baik dalam bentuk sebenarnya maupun dalam bentuk tiruan yang dipertunjukkan oleh guru atau sumber belajar lain yang ahli dalam topik bahasan. Pendapat lain menyatakan bahwa metode eksperimen adalah cara mengajar dimana seorang instruktur atau tim guru menunjukkan, memperlihatkan suatu proses (Roestiyah, 2001: 82-83).

Prestasi adalah hasil dari suatu kegiatan yang telah dikerjakan, diciptakan baik secara individu maupun kelompok. Poerwadarminta,berpendapat bahwa prestasi 
adalah hasil yang telah dicapai(dilakukan,dikerjakan,dan sebagainya). Qahar, persatasi adalah apa yang telah kita dapat ciptakan, hasil pekerjaan, hasil menyenangkan hati yang diperoleh dengan jalan keuletan. Nasrun Harahap dkk, prestasi adalah penilaian pendidikan tentang perekembangan dan kemajuan murid yang berkenaan dengan penguasaan bahan pelajaran yang disajikan kepada mereka serat nilai-nilai yang terdapat dalam kurikulum.

Morgan (Gino, 1988:5) belajar adalah merupakan salah satu yang relatif tetap dari tingkah laku sebagai akibat dari pengalaman. Dengan demikian dapat diketahui bahwa belajar adalah usaha sadar yang dilakukan manusia melalui pengalaman dan latihan untuk memperoleh kemampuan baru dan merupakan perubahan tingkah laku yang relatif tetap, sebagai akibat dari latihan. Dengan kata lain dapat dikatakan bahwa belajar itu meliputi setiap pengalaman yang menimbulkan perubahan dalam pengetahuan, sikap dan ketrampilan seseorang, baik perubahan bersifat positif maupun negatif, baik sengaja maupun tidak sengaja, baik terjadi di dalam sekolah maupun diluar sekolah. Sardiman (2002:88) belajar adalah suatu proses perubahan yaitu tingkah laku sebagai hasil pengalamannya sendiri dalam proses interaksi dengan lingkungan. Perubahan itu adalah didapatkannya kemampuan baru, yang berlaku dalam waktu yang relatif lama dan perubahan itu terjadi dikarenakan usaha.

IPA merupakan hasil kegiatan manusia berupa pengetahuan, gagasan dan konsep yang terorganisasi tentang alam sekitar, yang diperoleh dari pengalaman melalui serangkaian proses ilmiah antara lain penyelidikan, penyusunan dan pengujian gagasan-gagasan. Mata pelajaran IPA adalah program untuk menanamkan dan pengembangan pengetahuan, ketrampilan, sikap, dan nilai ilmiah pada siswa serta rasa mencintai dan menghargai kebesaran Tuhan Yang Maha Esa, Kurikulum Sekolah Dasar (1994:73). Fungsi memberi pengetahuan mengenai berbagai jenis dan perangai lingkungan alam dan lingkungan buatan dalam kaitannya dengan pemanfaatannya bagi kehidupan sehari-hari, mengembangkan ketrampilan proses, mengembangkan wawasan, sikap dan nilai yang berguna bagi siswa untuk meningkatkan kualitas kehidupan sehari-hari, mengembangkan kesadaran tentang adanya hubungan keterkaitan yang saling mempengaruhi antara kemajuan IPA dan teknologi dengan keadaan lingkungan dan pemanfaatannya bagi kehidupan sehari-hari, mengembangkan kemampuan untuk menerapkan ilmu pengetahuan dan teknologi serta ketrampilan yang berguna dalam kehidupan sehari-h-hari maupun untuk melanjutkan pendidikannya yang lebih tinggi. Tujuan pembelajaran IPA yakni memahami konsep-konsep IPA dan keterkaitannya dengan kehidupan sehari-hari, memiliki ketrampilan proses untuk mengembangkan pengetahuan gagasan tentang alam sekitar, mempunyai minat untuk mengenal dan mempelajari benda-benda serta kejadian di lingkungan sekitar, bersikap ingin tahu, tekun, kritis, bertanggung jawab, bekerja sama dan mandiri, mampu menerapkan berbagai konsep IPA untuk menjelaskan gejala $\neg$-gejala alam dan memecahkan masalah dalam kehidupan seharihari, dan mampu menggunakan teknologi sederhana yang berguna untuk memecahkan suatu masalah yang ditentukan dalam kehidupan sehari-hari $\neg$ (Djamarfah, 2006:16).

Djamarah (2006:56) metode eksperimen dikatakan cara penyajian pelajaran di mana siswa melakukan percobaan dengan mengalami dan membuktikan sendiri sesuatu yang dipelajari. Kemudian Mulyani Sumantri, dkk (1999) mengatakan bahwa metode eksperimen diartikan sebagai cara belajar mengajar yang melibatkan siswa dengan mengalami dan membuktikan sendiri proses dan hasil percobaan. Menurut Roestiyah (2001:80) Metode eksperimen adalah suatu cara mengajar, di mana siswa melakukan suatu percobaan tentang sesuatu hal, mengamati prosesnya serta menuliskan hasil percobaannya, kemudian hasil pengamatan itu disampaikan ke kelas dan dievaluasi oleh guru. Schoenherr (1996) yang dikutip oleh metode eksperimen adalah metode yang sesuai untuk pembelajaran sains, karena metode eksprimen mampu memberikan kondisi belajar yang dapat mengembangkan kemampuan berfikir dan kreativitas secara optimal. Siswa diberi kesempatan untuk menyusun sendiri 
konsep-konsep dalam struktur kognitifnya, selanjutnya dapat diaplikasikan dalam kehidupannya Palendeng (2003:81). Sedang Al-farisi (2005:2), metode yang bertitik tolak dari suatu masalah yang hendak dipecahkan dan dalam prosedur kerjanya berpegang pada prinsip metode ilmiah. Dan Mbulu, (2001:58) metode eksperimen adalah cara penyajian bahan pelajaran di mana siswa melakukan eksperimen (percobaan) dengan mengalami dan membuktikan sendiri sesuatu yang dipelajari.

Agar pelaksanaan eksperimen dapat berjalan lancar maka: (1) Guru hendaknya merumuskan tujuan eksperimen yanga akan dilaksanakan murid (2) Guru bersama murid mempersiapkan perlengkapan yang dipergunakan (3) Perlu memperhitungkan tempat dan waktu (4) Guru menyediakan kertas kerja untuk pengarahan kegiatan murid (5) Guru membicarakan masalah yanga akan yang akan dijadikan eksperimen (6) Membagi kertas kerja kepada murid (7) Murid melaksanakan eksperimen dengan bimbingan guru, dan (8) Guru mengumpulkan hasil kerja murid dan mengevaluasinya, bila dianggap perlu didiskusikan secara klasikal. Kelebihan metode Eksperimen dapat membuat anak didik lebih percaya atas kebenaran atau kesimpulan berdasarkan percobaannya sendiri daripada hanya menerima kata guru atau buku, anak didik dapat mengembangkan sikap untuk mengadakan studi eksplorasi (menjelajahi) tentang ilmu dan teknologi, dengan metode ini akan terbina manusia yang dapat membawa terobosan-terobosan baru dengan penemuan sebagai hasil percobaan yang diharapkan dapat bermanfaat bagi kesejahteraan hidup manusia, anak didik memperoleh pengalaman dan keterampilan dalam melakukan eksperimen, siswa terlibat aktif mengumpulkan fakta dan informasi yang diperlukan untuk percobaan, dapat menggunakan dan melaksanakan prosedur metode ilmiah dan berfikir ilmiah, dapat memperkaya pengalaman dan berpikir siswa dengan hal-hal yang bersifat objektif, realitas dan menghilangkan verbalisme.

\section{METODE}

Penelitian Tindakan Kelas (PTK) yang merupakan suatu penelitian tindakan dalam bidang Pendidikan yang bertujuan untuk memperbaiki atau meningkatkan mutu pembelajaran di kelas. Penelitian Tindakan Kelas merupakan suatu bentuk penelitian yang bersifat reflektif dengan melakukan tindakan-tindakan tertentu agar dapat memperbaiki atau meningkatkan praktek pembelajaran di kelas secara proposional. Penelitian tindakan kelas ini dilaksanakan dalam empat tahap, yaitu (1) tahap perencanaan (2) tahap pelaksanaan (3) tahap pengamatan, dan (4) tahap refleksi. Data diperoleh dari pengamatan, tes dan dokumentasi. Data dalam penelitian ini bersifat kuantitatif dan kualitatif. Data kuantitatif berupa peningkatan Prestasi Belajar siswa setelah dilakukan penelitian tindakan. Data kualitatif menerangkan minat siswa dalam belajar, suasana kelas, dan aktivitas siswa.

\section{Rancangan Penelitian}

Penelitian ini merupakan salah satu upaya guru atau praktisi dalam bentuk berbagai kegiatan yang dilakukan untuk memperbaiki dan atau meningkatkan mutu pembelajaran di kelas. Tujuan PTK adalah (1) memperbaiki dan meningkatkan kualitas pembelajaran serta membantu memberdayakan guru dalam memecahkan masalah pembelajaran di sekolah, (2) meningkatkan dan/atau memperbaiki praktik pembelajaran di sekolah, meningkatkan relevansi pendidikan, meningkatkan mutu pendidikan. Pelaksanaan penelitian ini berbentuk siklus yang terdiri dari 3 siklus yang masing-masing meliputi: planning (perencanaan), action (pelaksanaan), observation (pengamatan) dan replection (refleksi).

\section{Perencanaan}

Pada tahap perencanaan dilaksanakan kegiatan mengidentifikasi masalah yang muncul. Untuk siklus I dan II didasarkan pada hasil refleksi. Merencanakan pembelajaran yang disusun dalam RPP sesuai dengan materi dan model pembelajaran eksperimen. Menyusun LKS sesuai dengan materi. Menyiapkan sumber 
Vol. 2 No. 3, Juli 2018;

belajar sesuai dengan materi yang diajarkan. Menentukan media pembelajaran sesuai dengan materi. Menyusun soal evaluasi sesuai dengan materi.

\section{Pelaksanaan Tindakan}

Tahap pelaksanaan tindakan dilakukan dengan menerapkan model pembelajaran eksperimen. Proses pembelajaran dilaksanakan mengacun pada Rencana Pelaksanaan Pembelajaran (RPP).

\section{Pengamatan}

Tahap pengamatan dilakukan dengan cara mengamati aktifitas belajar siswa selama kegiatan inti pembelajaran berlangsung. Dari hasil pengamatan akan diperoleh sampai seberapa jauh keaktifan siswa dalam proses pembelajaran.

\section{Refleksi}

Tahap refleksi merupakan tahap yang sangat penting. Peneliti harus benarbenar jeli dalam memberikan refleksi. Setelah selesai melaksanakan pembelajaran maka peneliti harus dapat memberikan refleksi yang tepat, sehingga hasil refleksi tersebut dapat dianalisis dengan tepat pula. Tahapan ini merupakan kegiatan mengevaluasi dan meninjau kembali pelaksanaan pembelajaran dan hasil observasi yang dilakukan sebagai bahan pertimbangan untuk perbaikan atau perumusan tindakan lebih lanjut Dari evaluasi dan observasi, digunakan untuk merefleksi sejauh mana tingkat perubahan hasil belajar siswa. Hasil ini akan dipergunakan sebagai acuan untuk melangkah ke siklus selanjutnya.

\section{Teknik Pengumpulan Data}

Data dikumpulkan dengan menggunakan teknik pengumpulan data tes dan non tes. Teknik tes diperguanakan untuk memperoleh data tentang prestasi belajar siswa. Sedangkan data non tes dipergunakan untuk memperoleh data tentang aktifitas siswa.

\section{Teknik Analisis Data}

Penelitian ini menggunakan teknik analisa deskriptif kualitatif, yaitu suatu metode penelitian yang bersifat menggambarkan kenyataan atau fakta yang sesuai dengan data yang diperoleh dengan tujuan untuk mengetahui prestasi belajar yang dicapai siswa juga untuk memperoleh respon siswa terhadap kegiatan pembelajaran serta aktivitas siswa selama prose pembelajaran. Untuk menganalisis tingkat keberhasilan atau prosentase keberhasilan siswa setelah proses belajar mengajar setiap putarannya dilakukan dengan cara memberikan evaluasi berupa soal tes tertulis pada setiap akhir putaran. Analisis ini dihitung menggunakan statistik sederhana yaitu peneliti melakukan penjumlahan nilai yang diperoleh siswa, yang selanjutnya dibagi dengan jumlah siswa yang ada di kelas tersebut sehingga diperoleh rata-rata tes formatif.

\section{HASIL}

Hasil pra siklus sebelum penelitian tindakan kelas dilakukan berdasarkan hasil evaluasi yang telah dilakukan di Kelas IV SDN 2 Ngulankulon Kecamatan Pogalan Kabupaten Trenggalek Semester 2 tahun pelajaran 2016/2017 yang berjumlah 24 siswa prestasi belajar beberapa siswa masih rendah, nilai di bawah KKM 70. Rata-rata Hasil nilai IPA adalah 67,9; siswa yang mendapat nilai $>70$ berjumlah 11; prosentase ketuntasan individual (> 70) sebesar 45,8 \%. Perbandingan siswa yang mendapatkan nilai di atas KKM adalah sebanyak 11 siswa sedangkan siswa yang mendapatkan nilai di bawah KKM adalah sebanyak 13 siswa, dengan nilai tertinggi adalah 80 dan nilai terendah adalah 60 .

Hasil siklus I pembelajaran dengan menggunakan metode eksperimen selama dua kali pertemuan dengan pokok bahasan pengertian gaya dan sifat-sifat gaya, nilai 
Vol. 2 No. 3, Juli 2018;

di atas KKM sebanyak 17 siswa sedangkan siswa yang mendapatkan nilai di bawah KKM sebanyak 7 siswa, dengan nilai tertinggi 90 dan nilai terendah adalah 60 . Refleksi siswa memiliki kekurangan dalam memahami materi pembelajaran yang disampaikan oleh guru yang selama ini selalu menggunakan metode konvensional, yaitu ceramah. Siswa hanya disuruh untuk melihat buku paket dan menghafalkan materi yang diajarkan oleh guru. Hal ini membuat siswa tidak tertarik, bosan, mengantuk dan bermain sendiri di dalam kelas selama proses belajar mengajar. Siswa juga tidak antusias dan takut menjawab jika diberi pertanyaan oleh guru tentang materi yang diajarkan karena tidak adanya media pembelajaran yang nyata, siswa hanya dapat membayangkan. Hasil siklus II siswa yang mendapatkan nilai yang tuntas adalah sebanyak 21 siswa sedangkan siswa yang mendapatkan nilai yang tidak tuntas adalah sebanyak 3 siswa, dengan nilai tertinggi adalah 100 dan nilai terendah adalah 60 . Sesuai dengan indikator kinerjanya bahwa $75 \%$ siswa telah mengalami ketuntasan individual, maka pelaksanaan siklus II yang baru mencapai ketuntasan $87,5 \%$ (berhasil), sehingga tidak perlu dilanjutkan pada siklus III.

\section{PEMBAHASAN}

Hasil observasi sebelum tindakan yang dilakukan di Kelas IV SDN 2 Ngulankulon Kecamatan Pogalan Kabupaten Trenggalek Semester 2 tahun pelajaran 2016/2017 menyatakan bahwa Prestasi Belajar siswa terhadap pembelajaran IPA tentang gaya pada sebagian besar siswa masih rendah dengan ditandai dari banyaknya siswa yang mendapatkan nilai di bawah KKM 70. Hal ini salah satunya disebabkan oleh cara penyampaian materi pembelajaran masih menggunakan metode konvensional atau ceramah. Pra Siklus, proses pembelajaran sebelum tindakan menunjukkan Prestasi Belajar yang rendah pada sebagian besar siswa dengan jumlah siswa yang mendapatkan nilai di bawah KKM adalah 13 siswa $(54,2 \%)$ di mana nilai terendahnya adalah 60 . Siklus I, dengan menggunakan metode eksperimen pada pembelajaran IPA tentang gaya Kelas IV SDN 2 Ngulankulon Kecamatan Pogalan Kabupaten Trenggalek semester 2 tahun pelajaran 2016/2017 pada siklus I, sebanyak 17 siswa mendapatkan nilai memenuhi KKM dengan nilai tertinggi 90, sedangkan 7 siswa mendapatkan nilai di bawah KKM dengan nilai terendah 60. Siklus II, dengan menggunakan metode eksperimen pada pembelajaran IPA tentang gaya Kelas IV SDN 2 Ngulankulon Kecamatan Pogalan Kabupaten Trenggalek Semester 2 tahun pelajaran 2016/2017 pada siklus II, 21 siswa mendapatkan nilai memenuhi KKM dengan nilai tertinggi 100. Sedangkan 3 siswa (mendapatkan nilai di bawah KKM.

\section{KESIMPULAN}

Berdasarkan hasil penelitian yang telah dipaparkan pada Bab IV, maka dapat diambil kesimpulan bahwa Pembelajaran IPA tentang gaya dengan metode eksperimen dapat meningkatkan Prestasi Belajar siswa Kelas IV SDN 2 Ngulankulon Kecamatan Pogalan Kabupaten Trenggalek Semester 2 tahun pelajaran 2016/2017 . Hal itu dapat dilihat dari Prestasi Belajar siswa pada tes pembelajaran siklus I siklus II dan siklus III. Rata-rata nilai siswa saat pra siklus adalah 67,9 Setelah siklus I dilakukan, rata-rata nilainya meningkat menjadi 74,6 . Sedangkan setelah siklus II, ratarata nilai siswa meningkat menjadi 80,8 . Pembelajaran IPA tentang gaya dengan metode eksperimen dapat meningkatkan jumlah persentase siswa yang mendapatkan nilai memenuhi KKM 70. Hal itu dapat dilihat dari perbandingan jumlah siswa yang mendapatkan nilai memenuhi KKM siklus I dan siklus II. Ketuntasan klasikalpun mengalami peningkatan dari pra siklus $45,8 \%$ meningkat menjadi $70,8 \%$ pada siklus I dan pada siklus II menjadi $87,5 \%$. Implementasi metode eksperimen dalam mata pelajaran IPA dapat meningkatkan Prestasi Belajar siswa Kelas IV SDN 2 Ngulankulon Kecamatan Pogalan Kabupaten Trenggalek Semester 2 tahun pelajaran 2016/2017.

\section{SARAN}


Vol. 2 No. 3, Juli 2018;

Peneliti merekomendasikan kepada para Guru khususnya, agar kegiatan belajar mengajar dapat berlangsung dengan tertib serta mencapai Prestasi Belajar optimal, maka hal-hal yang dapat dijaidikan pertimbangan bagi Guru bermanfaat untuk mengubah wawasan, pengarahan dan ketrampilan mengajar dengan menggunakan metode eksperimen, serta membantu guru untuk mengubah cara mengajar yang selama ini bersifat konvensional dan sebagai bahan masukan guru dalam meningkatkan mutu pendidikan di kelas yang diampunya. Bagi siswa untuk memudahkan dan memahami suatu konsep materi ajar, serta menjadikan kreatif dan senang guna meningkatkan Prestasi Belajar siswa dalam bidang studi IPA. Bagi orang tua bermanfaat untuk mengetahui perkembangan siswa dalam mengikuti kegiatan pembelajaran putra-putrinya serta untuk ikut memberikan bimbingan agar hasil yang dicapai dapat meningkat. Bagi sekolah bermanfaat untuk meningkatkan mutu pendidikan sekolah dengan meningkatnya prestasi belajar siswa, serta dapat menambah dokumentasi untuk dipajang dalam majalah dinding dan koleksi foto saat pembelajaran berlangsung dibuat kliping dan ditempatkan di perpustakaan sekolah.

\section{DAFTAR RUJUKAN}

Ahmad Rivai, Nana Sudjana. 2003. Media Pengajaran. Bandung: Sinar Baru Algensindo.

Al-Farisi. 2005. Startegi Pembelajaran. Jakarta: Rajawali Pres

Depdikbud.1994. Kurikulum Pendidikan Dasar (GBPP). Jakarta: Depdikbud

Djamarah, S, B. 2006. Strategi Belajar dan Pembelajaran. Reneka Cipta. Jakarta

Gino, 1988. Teori - teori Belajar menurut para ahli. http://visiuniversal.blogspot.com/2014/03/pengertian-belajar-dan-macammacam.html\#sthash.Yhex8WMt.dpuf, diakses 15 Maret 2016

Joseph, Mbulu. 2001. Pengajaran Individual: pedekatan,Metode dan Media Pedoman Mengajar Bagi Guru dan Calon Guru. Malang: Elang Mas

Mulyani, dkk., 1999. Strategi Belajar Mengajar. Jakarta :Direktorat Jendral Pendidikan Tinggi

Nasrun, Harahap. 1994. Penelitian Hasil Belajar. Surabaya: Usaha Nasional.

Palendeng. 2003. Strategi Pembelajaran Aktif. Jakarta: Rineka Cipta

Poerwadarminta. 2003. Kamus Umum Bahasa Indonesia. Jakarta: Balai Pustaka.

Prabowo, 2000. Pembelajaran Fisika dengan Pendekatan Terpadu dalam Menghadapi Perkembangan IPTEK Milenium III. UNESA

Qohar, Mas'udKhasan Abdul, 1998. Kamus IImiyah Populer. Jakarta: Bintang Pelajar

Roestiyah, N.K. 1991.Strategi Belajar Mengajar. Jakarta: Bhineka Cipta

Roestiyah 2001. Strategi Belajar Mengajar. Jakarta: Rineka Cipta.

Sardiman, AM. 2002. Interaksi Dan Motivasi Belajar Mengajar. Jakarta: Rajawali 